\title{
Ghosts, Memory and the Right to the Divided City: Resisting Amnesia in Beirut City- Centre
}

\section{Introduction}

Violently divided cities - like Beirut, Sarajevo, Jerusalem and Belfast - experience a deep sectarian conflict over the legitimacy of state sovereignty. In response to the catastrophic destruction visited on these cities, postwar reconstruction expedites urban economic development, comprising adaptive commercial reuse and gentrification, designating areas of the city as artistic quarters, and some form of historical preservation. These reconstruction projects focus on the city-centre and its rebuilding symbolizes the successful face of the peace process. Many contemporary metropolises - regardless of whether sectarian conflict has occurred - encourage "urban cloning," an identikit regeneration scheme drawing on a sanitized version of localism. Such models of urban development either tame or romanticize the disorderliness of the lived city, its logic flattening out complex spatialities (Till 2012:5).

Numerous case-studies have linked these projects to neoliberal and revanchist forms of expropriation which mask continuing public disinvestment and economic inequality in postindustrial cities (see Smith 2002; Mitchell 2003; Harvey 2012). Yet, how do these processes relate to divided cities? In divided cities, neoliberal urban regeneration often intersects with the ideals of the "capitalist peace," an attempt to discipline these places into pacification through incentivizing foreign direct investment and promoting gentrification and privatization strategies (see Millar 2015). In fact, some scholars claim that since lasting peace is reliant upon capitalist economic development, it is imperative to forcibly expose postwar states to market liberalization, land privatization, foreign investment and export diversification (Keen 2005). The logic driving such theories is that weak and divided states, which are unable to produce adequate public goods, can instead generate development, 
political stability and economic restoration through strong free-market institutions (Selby 2013). Economic liberalism is said to even encourage "market citizenship" (see Hughes 2015:912), wherein members of divided societies are persuaded to abandon entrenched ethnic interests in preference for the values of possessive individualism. However, rather than incentivize intracommunal reconciliation, research on the "privatization of peace" points to its aggravating consequences for ethnic divisions and for driving new forms of social exclusion (Richmond 2011). It facilitates, furthermore, sectarian elites and warlords to degrade public goods and to capture, via clientelism and corruption, economic and political institutions (Leenders 2004).

Yet, lacking in this literature is an understanding of how neoliberal postwar reconstruction legitimates sectarian and class cleavages by programming specific narratives into rebuilt space in divided cities. I address this by exploring the embedding of amnesia into urban space. This paper illuminates the nexus between neoliberal postwar reconstruction and the material construction of forgetting in divided cities. The programming of amnesia into urban space functions to elide reference to the recent history of sectarian violence in the divided city, which in turn contributes to a pernicious logic perpetuating ethnic conflict and socioeconomic inequity.

These issues are evident in postwar Beirut, the capital of Lebanon. Discussing Beirut citycentre's reconstruction, Khalaf (2012) argues it obscures the "retribalization" of space across post-civil war Lebanon as groups increasingly shelter in cloistered ethnic communities. Marot and Rigizi (2012) view the "gentrification" of Beirut city-centre as planting the "seeds of future socio-political unrest" by expediting "a level of inequality comparable to that which, in part, led to the outbreak of civil war." Urban reconstruction in Beirut not only disguises the cracks exposed by enduring patterns of sectarian division and socioeconomic stratification, it also cleanses public space of troubled histories. The rebuilding of Beirut's 
city-centre represents "a desire for collective amnesia, wiping away all reminders of the conflict" (Wainwright 2015). Beirut city-centre is "the forgetful landscape," a "concerted effort to bury and to deny the country's more recent past” (Nagel 2002:724).

While it is necessary to record the structural problems that cause failed postwar reconstruction projects, like Beirut (Till 2012), it is important not to view the inhabitants in divided cities as passive victims. Rather than seeing postwar reconstruction as creating power as ubiquitous and insidious, power is instead a "versatile equilibrium", with "complementarity and conflicts," (Foucault 1999:162) and where forms of "subversive agency" exist which elude or resist the interests of sectarian elites. These concerns connect with contemporary debates concerning how local populations exercise critical agency in the face of postwar institution building. Critical agency "reconstructs legitimacy for subjects who reclaim it from power and structure" (Richmond 2011:428).

I note the hegemonic incompleteness of these reconstruction schemes. The elisions of such projects open up space for complex forms of engagement by non-state actors. Rather than simply reproduce or challenge state power, some ethnic movements construct regimes of "civic governmentality," which recreate the terms of rule and citizenship (Roy 2009). Other ethnic movements may instead advance sectarian interests, foment intercommunal antagonism, and even spawn collective violence as they resist or demand their share of space and resources in the divided society (Nagle, 2016). Yet, given how reconstruction strategies entrench social forgetting as a form to legitimate dispossession, resistance may also be articulated by social movements that cross-cut ethnic cleavages to create strategies of resistance to forgetting through right-to-the-city claims.

Towards this, I examine social movements contesting Beirut city-centre space in two interrelated ways. First, these movements transform segregated and privatized space into 
places that encourage open access and participatory democracy. Secondly, social movements challenge the programming of city-centre space as a political aesthetic encouraging political amnesia about the past violent conflict. Movements do this by linking memory to the rightto-the-city and participatory democracy. Thus, right-to-the-city movements harness the power of memory, haunting, ghosts and history as a way of fostering peacebuilding and as a means to demand access to municipal services in the present. Narratives and memory-work are devices that allow groups to "confront and take responsibility for the failures of the democratic state and its violences" (Till 2012:6). In particular, I link Lefebvre's right-to-thecity with the idea of ghosts and haunting, the strategy of making what is concealed - and thus used to legitimate sectarian division and economic injustice - visible and therefore open to transformation. If postwar reconstruction expedites disappearance and dispossession through amnesia, radical movements reveal what Arendt (1958) termed a "space of appearance," a sphere of political action where citizens coalesce to produce agency, power and collective action.

In this article I explore three contemporary non-sectarian Beiruti movements: a victims' movement, a movement dealing with the city-centre's architectural heritage, and a movement resisting the privatization of public space. These right-to-the-city movements see themselves as part of the urban majority marginalized from the democratic process of reshaping the postwar city. In different ways they programme memory into the city-centre as a way of making the state and wider society confront the conjoined forces of sectarianism and class-based injustice.

While these movements refuse to belong to ethnic groups, neither do they cohere to specific socioeconomic classes. These movements, however, expose the different ways in which postwar city-centre reconstruction marginalizes various social groups and silences alternative forms of politics to a neoliberal ethnocommunalism. Victims' movements, therefore, 
illuminate how they are the result of the state refusing to recognize the legacy of its violent past. The movement enters the amnesiac downtown to force the state and society to accept the existence of the disappeared. The movement to protect the city's architectural heritage demands that key civil war buildings can be used as a basis for providing memory for a city that is unable to understand how its sectarian history haunts the present. The movement to defend the commons utilize memory to remind urban citizens of a past when public space was vital to fostering some degree of intracommunal interaction and civility.

In this sense, the movements analysed in this article provide both overlapping and, at times, different approaches to the right-to-the-city. In reflection of these complex dynamics, the methodological approach for this research is diverse. Ethnographic fieldwork was conducted during four fieldwork phases (September 2012, July 2014, June 2015, January 2016), each of which lasted from one week to a month. Interviews (N-29) in Beirut included leading activists in Helem, AUB Secular Society, SOLIDE, ACT, UMAN, Dalieh and activists associated with architecture and urban regeneration.

\section{Beirut: The Divided City}

A violent conflict over the legitimacy of the state motivates discord in divided cities. In divided cities social identities are constrained by ethnonational allegiances, which provide little room for multiple encapsulations crosscutting the cleavages. Civic, social life and political mobilization, consequently, tend to occur within cleavages, buttressed by historically embedded patterns of social segregation and endogamy (Nagle and Clancy 2010: 1). Rather than see these divisions as primordial, they are typically constructed through colonial divide et impera and/or modern state-building processes.

Beirut's status as a divided city is traced to Modern Lebanon's formation by the French in 1920 to ensure an inbuilt majority of Christians over Muslim sects. The state incorporated 
new territories containing a large Sunni population, which in contrary to professing loyalty to this new state, wished instead for unification with co-ethnics in neighbouring Syria (Traboulsi 2007). Political and economic resources were directed in favour of Christians (Picard 2002) and Beirut became the centre of their power, despite the city containing many Muslims.

Lebanon gained independence in 1943 and the respective Christian and Muslim elites forged the National Pact to share power in the new state. While this system promised to regulate horizontal ethnic interests, it widened vertical class cleavages (Picard 2002). Beirut experienced a period of economic growth; yet this deepened the rift "between the center (Beirut) and the periphery, the elites and the masses, and created a never-before experienced socioeconomic gap that closely mapped onto religious affiliation” (Zahar 2005:229).

The internal weaknesses of Lebanon's sectarian and class cleavages intersected with regional geopolitical divisions. A simplistic reading of the civil war, which began in 1975, presents it as a Christian/Muslim conflict. The war was extremely complex and underwent a number of phases, including interventions by Syria and Israel, and the Palestinian Liberation Army acted as a major belligerent. The civil war, which ended in 1990, resulted in 144,000 deaths and 1.3 million displaced people (Harris 2012:235). While prior to the war Beirut was undeniably divided by political sectarian cleavages, residential mixing between groups was common (Kassir 2011). The war, however, vanished "all memories of coexistence and common interests between the Lebanese" (Traboulsi 2007:38) as "strategies of accommodation and avoidance were replaced by strategies of confrontation and radicalization" (Picard 2002:153). For example, the Muslim population of east Beirut declined from 40 to 5 per cent during the civil war (see Khalaf 2012:83). 
Beirut city-centre was the strategic frontline of the civil war as the rival militias vied to control the district. The city-centre represented the "Green Line," dividing Christian and Muslim Beirut. Approximately thirty percent of buildings in the historic downtown area were destroyed. Across the city, a consequence of the war was the creation of more ethnically homogeneous and exclusive spaces, which have the effect of consolidating the exercise of local power by former ethnic militia warlords now reinvented as political leaders. ${ }^{1}$ Postwar Beirut has undergone remilitarization as the various "sectarian militias reorganized and rearmed themselves, and urban space was physically and symbolically divided into exclusive sectarian ghettos" (Salloukh et al. 2015:29). ${ }^{2}$

The war ended with the Taef Agreement (1989), which restored power-sharing. Taef aimed to end violence by accommodating Lebanon's main ethnoreligious sects - particularly Christian, Sunni, Shia and Druze - in the state's institutions. Lebanon's power-sharing enshrines the concept of the "allotment state" (muhasasa): each group is guaranteed representation in the polity by means of a quota system that reflects the assumed demographic balance (Leenders 2004). While power-sharing was supposed to incentivize communal elites to engage in moderate behaviour, it "is deployed instrumentally by a sectarian/political elite bent on reproducing sectarian identities and obviating the emergence of alternative, trans-sectarian or non-sectarian, modes of political mobilization" (Salloukh et al. 2015:2).

One consequence of Lebanon's power-sharing is the "synergy between the overlapping sectarian/political and economic elite" that plays "an instrumental role in the reproduction of sectarian modes of subjectification" (Salloukh et al. 2015:6). Taef and the constitution specified laissez-faire policies as enabling peace (Leenders 2004). Horizon 2000, the government's 1993 plan, foresaw total private investments to reach levels twice as high as public investments (Leenders 2004:174). However, given that power-sharing was to 
accommodate conflicting ethnoreligious groups, the formation of public policy came to be dominated by informal bargaining between elites. The most common outcome of this bargaining was the apportionment of the spoils of public office, privileges, and state resources between the sectarian elites (Leenders 2004:179-80).

Through devolving power to a small clique, these elites captured the state to serve their own economic and political interests (Traboulsi 2007). A social movement activist explained to me that rather than power-sharing, the system is better called "pie sharing," as it reflects the capacity of elites to sequester resources for their own personal enrichment. At the same time, since power-sharing is to "perpetuate sectarianism as the foundation of politics," (Cammett 2014:64) these elites utilize divisive rhetoric to maintain their position of power within ethnoreligious groups. This intersection between sectarian and socioeconomic division is made material through the postwar reconstruction of Beirut city-centre.

\section{Rebuilding Peace}

Given the destruction of Beirut city-centre during the civil war, the regeneration of the citycentre was conducted to discipline it into peace by making it the nation's commercial centre. Beirut was seen as particularly receptive to postwar reconstruction within the remit of the Washington consensus. The World Bank concluded: "unlike most of its neighbors, Lebanon never flirted with statism and the country was renowned for its laissez-faire policies, its minimalist state, and its entrepreneurial tradition" (Leenders 2004:170).

The regeneration of Beirut city-centre was initiated in 1991 by the introduction of a new law, 117, deliberately created for expediting reconstruction. Under the aegis of law 117, jurisdictional power was granted to the municipality of Beirut to expropriate city-centre properties (Makdisi 1997). Based on the assumption that the state was too fiscally weak to finance reconstruction, in 1994 a private company, Solidere, owned by Rafiq Hariri, the 
Lebanese Prime Minister, was setup to redevelop what was subsequently termed "Beirut Central District" (Leenders 2004). Framed as a project that served the "public interest," Solidere was granted "special powers of compulsory purchase and regulatory authority, giving it the mandate to manage the city-centre like a mini-fiefdom" (Wainwright 2015). Operating as a "private-public hybrid" (Wainwright 2015) entity, Solidere represents the "colonization" of the public sector by the private, and the "dissolution of any real distinction between public and private interests." All assets held by more than 120,000 original claimants to property rights in the area were transferred to Solidere (Leenders 2004:183) and Solidere have redeveloped 200 hectares of land and its acquired properties are worth \$8billion (Solidere, 2011: 7), approximately one quarter of Lebanon's GDP. The reconstruction of the city-centre corresponded to the allotment state as Solidere compensated the representatives of the main sectarian parties (Leenders 2004; Roy, 2009:170-171).

Solidere presents itself as a healing agency, designed to help central Beirut recover from its afflictions (Makdisi 1997:675) by producing a conflict-free zone to symbolize Lebanon’s ability to overcome its divisions and re-emerge as a modern city. In annual reports Solidere (2009:16) identifies Rafiq Hariri as the "Godfather of national recovery." Solidere's "masterplan" proclaims that "Solidere is vested with a ... historical mission: restoring life to this vital part of the country, an important political and symbolic dimension," which contributes to national reconciliation (Solidere 2015). The first phase of the reconstruction replaced the destroyed traditional souk with a shopping mall costing \$300 million.

Successive waves concentrated on the banking district before spreading out to the waterfront, which hosts an exclusive yacht club, nightclubs and restaurants, and gated residential communities. Solidere's gentrification of the city-centre did not simply rehabilitate "physical infrastructure;" it is an "attempt to reinterpret Lebanon's tumultuous past" and to "create a new collective memory" (Nagel 2002:717) for the nation. 
The logic undergirding the city-centre's reconstruction was two-fold: to project the nation both externally and internally. Externally, the idea was to construct an image of the citycentre as a global city, to restore Beirut's reputation as the financial hub of the Middle East. Internally, the successful rebuilding of city-centre, and thus the economy, was meant to stand as a symbol of Lebanon's reclaimed sense of nationhood. Yet, the project contained contradictory dynamics. On the one hand, to conjure up the aura of a global city, space would need to be denationalized through being rendered abstract, a city without any discernible local or regional identity. On the other hand, to become the nation's unifying capital again, the nationalizing of space required grounding in territory, memory and history. Ultimately, the city-centre was rebuilt by deterritorializing space, by liberating it "from all existing codes and reference points to both past and present" (Yaha 2004). The delineation of memory embodied in the regeneration programme is "not about addressing the trauma associated with ... the civil wars"; it is instead about "about forgetting, that is the replacement or displacement of that past with another" (Yaha 2004).

\section{Ghosts and Haunted Ruins}

Yet, despite attempts to purify the Beirut city-centre of its violent past and present, ghosts and ghostly ruins are found. "Ghosts," note Edensor (2005:835), "haunt the regulated city and the impossible dreams of totalisation." Ghosts profoundly disturb those political imperatives designed to "bury the past too swiftly in search of the new" (Edensor 2005:829). While dominant strategies of urban regeneration stabilize memories and identities in particular spaces, ghosts are fluid, evanescent entities that "haunt the visitor with vague intimations of the past, refusing fixity, and they also haunt the desire to pin memory down in place" (Edensor 2005:829). 
Ghosts are never quiescent. They are noisy manifestations that disrupt "the reifications through which performances, narratives, and experiences of memory become fixed in space" (Edensor 2005:929). They also act as uncomfortable reminders of unresolved deep conflicts. Ghosts and hauntings, state Gordon (1997:2), are notifications of "what's been suppressed or concealed is very much alive and present, messing or interfering precisely with those always incomplete forms of containment and repression ceaselessly directed towards us." They are "haunting reminders" of the violence and the complex social relations in which we live (Gordon 1997:25). Rather than mute presences, ghosts occur "when the people who are meant to be invisible show up without any sign of leaving" (Gordon 1997:xvi).

Ghosts and haunted places, in the context of Beirut city-centre, upset attempts to entomb the violent past too soon for the lure of modernity. They are presences reminding the state of unaddressed human rights abuses, such as the "disappeared," of the need for justice to be served, and for the right-to-the-city. They are also powerful reminders that if the violent past continues to be ignored it will regress the potential for reconciliation and the growth of healthy public institutions as levels of socioeconomic inequality, segregation and intergroup distrust continue to grow. Since they irradiate narratives and injustices hitherto marginalized, the ghost "represents a future possibility" imagined in political alternatives (Gordon, 1997:63-64). Ghostly presences demonstrate that space is never completely imposed by the state. Ghosts and haunted places, as I see it, are the buildings that provide reminders of the civil war and the social movements that contest and even transform how space is currently programmed in the city-centre. "The rationality of the state," wrote Henri Lefebvre (1991:23), "its techniques, plans and programmes provoke opposition.” These seething forces of opposition "are still capable of rattling the lid of the cauldron of the state and its space, for differences can never be totally quieted." 
Beirut contains haunted buildings, reminders of the civil war that the reconstruction process cannot destroy. Completed in 1974 - only months before the civil war - and standing 26floors high, Beirut's Holiday Inn hotel currently resides an empty ruin. Pockmarked from the result of numerous rocket attacks, today the Holiday Inn rests as an anomalous hulking monument situated within the rebuilt downtown. The hotel has never been renovated as its various owners disagreed over its fate and it is "a de facto monument to destruction in a country whose leaders strive to forget the Civil War" (Stoughton 2014). Equally incongruous, just outside the city-centre limits are the disused remnants of Mar Mikhael train station. Demolished during fighting in the 1970s, Lebanon's train system was never revived. The station stands as a stark reminder of the state's priorities: that while billions of dollars have been pumped into the gentrification of the city-centre, Lebanon does not possess a basic infrastructure to support public services.

\section{The Right to the Divided City}

Hauntolology - the conflation of haunting and ontology - embodies the experience of historical dispossession caused by postwar urban regeneration in Beirut and the forms of resistance against such closure. Haunting illuminates how the meanings and usages attached to public space can never be programmed in ways that simply affirms the power of the state and its neoliberal partners. The power of ghosts and haunting expose spectacular urban regimes, which "are never coherent, exhaustive or closed in the ways they are fantasised as being" (Tagg 1996:1).

Ghosts and haunting, in the context of social movement mobilization in Beirut, can be coupled to Henri Lefebvre's ideas about the production of space and the tactics deployed by marginalized groups. Although Lefebvre did not write about violently divided cities, his writings about the political and social importance of urban space are certainly salient to these 
places. Lefebvre's worry about the corrosion of urban democracy in the form of "social segregation and material separation" (1996:154) is relevant for Beirut where sectarian division is institutionalized.

Lefebvre also makes us consider how space in divided cities is constructed in the service of antagonistic ethnonational projects and the failure of statist projects to provide worthwhile solutions as social segregation becomes increasingly normalized. Lefebvre $(1991 ; 1996)$ traced how states mobilize urban space as a productive force through infrastructural investment, spatial planning, industrial policy and financial regulation. More than this, the production of space required that its meaning and usage required meticulous programming. Urban space, claimed Lefebvre (1991:165), was rendered “closed, sterilized, emptied out.” The city was expropriated by the dominant class and a set of concomitant economic interests and public space was programmed to reflect this. Since the reproduction of social relations, and thus the survival of capitalism, is predicated upon the occupation and production of space, public space in cities is programmed for a specific function. While Lefebvre viewed the expropriation of public space for the purpose of private profit as a process that alienated most urbanites, he also recognized that it afforded ripe opportunities for radical urban movements to reclaim the city. If forms of urban regeneration attempt to expel "all peripheral elements with a violence that is inherent in space itself," this would be met with subversion from "countervailing forces" (Lefebvre1991:332).

A particularly important manifestation of social movement struggle, according to Lefebvre, is for the right-to-the-city. Henri Lefebvre's (1996) call for the right-to-the-city entails the right for citizens not only to inhabit urban spaces but also to participate in a city as an “oeuvre," an ongoing work of creation, production and negotiation. As such, Lefebvre's analysis is central to understanding how radical movements struggle to forge participatory democracy in the context of contemporary neoliberalism. For Lefebvre (1996) the highest 
form of participatory urban democracy required to overcome social divisions and alienation is the oeuvre - a work where all citizens participate; a collective, not a singular project emerges, and new modes of living and inhabiting are invented. Thus, while the "cry" is a response to the crisis of everyday life in the city, the demand represents a command to confront the crisis and to create an alternative urban life less alienated and open to encounters (Harvey 2012).

The struggle of urban social movements includes demands for better public services and a more equitable distribution of public resources. Yet, more than this, the right-to-the-city is a struggle to augment the rights of urban inhabitants against the property rights of owners. A key tactic as part of this strategy, stated Lefebvre (1991) was for social movements to "dealienate" urban space, to reintegrate it into the web of social connections. A necessary step in this process involved social movements re-appropriating and re-programming public space. The concept of "re-appropriation" was thus vital to Lefebvre's radical thinking to re-imagine and transform the fracturing of the city into discrete and alienated parts, to fight against “specialized space and a narrow localization of function” (1991:382-383). "Reappropriation" referred to how spaces could be reused by groups challenging how space is programmed to allow only specific functions to be performed at the expense of others (Uitermark 2004:709).

For Lefebvre (1996:159), it is necessary to multiply the readings of the city: the city contains abundant material to construct different stories that contradict the narratives of property developers. Lefebvre's (1991:54) argument that "a social transformation . . must manifest a creative capacity in its effects on daily life, on language and on space" links with many contemporary social movements' projects. Such movements are agents for bringing about change within societies. For this project to be successfully fashioned the seemingly chaotic heterogeneity of differences of the divided city requires that "different people with different 
projects must necessarily struggle with one another over the shape of the city, the terms of access to the public realm" (Mitchell, 2003:18). Moreover, the struggle of movements to create new spaces or to "re-appropriate" segregated space, through diverting its normalized uses, is simpatico with Lefebvre's call for groups to take up residence in and re-imagine spaces that have been programmed for the service of capitalism and inequality. Such reprogramming can include social movements reinserting memory into amnesiac spaces. This memory-work connects the concept of ghosts and haunting to Lefebvre's demand for urban participatory democracy. Indeed, "The right to represent the past ... can be considered a right-to-the-city and is intricately tied to the processes of democratization" (Till 2012:8).

\section{Beirut: "The Reconstruction Ideology"}

The postwar reconstruction of Beirut city-centre mirrored the attitude of Lebanon's political elite towards the memory of the civil war. During the war, thousands of civilians were abducted, often for purely sectarian reasons, and their bodies were never recovered. The Taef Agreement, however, did not mention victims nor did it suggest any mechanism for dealing with the legacy of the civil war. "The Lebanese state and society," Jaquemet (2009:69) argues, "have favored amnesia over truth seeking." Lebanon thus provides something of an anomaly in regards to postwar peacebuilding in divided societies - typically predicated on dealing with so-called issue like the victims of violence- which is a litmus test of whether a peace process should be judged successful (Nagle 2016:83). Lebanon's elite-led culture of social forgetting about the civil war is shaped by power-sharing. The motto of Lebanon's power-sharing - "no victor, no vanquished" - meant that none of the groups should be held accountable for the violence and duly punished.

The postwar political elites had a vested interested in promoting forgetting. Many of them were leading sectarian warlords responsible for civil war atrocities and they used their 
peacetime political offices to silence investigations and formal inquiries into the war (Jaquemet, 2009). Recognizing that they would be first to be prosecuted for war crimes, in 1991 the sectarian elites passed a general amnesty Law 84, which on a selective basis pardoned political crimes committed during the civil war (Picard 2002:165). As one civil society activist for victims explained, power-sharing "erected amnesia to a religion of state."

Solidere's reconstruction of Beirut city-centre became the material form of the elite's forgetfulness. Solidere saw its mission as providing "a therapeutic role by founding the city on a sort of salvation-like amnesia that would protect it from the old ghosts which caused its destruction" (Haugbolle 2011:86). For scholars and activists, Solidere's rebuilding project was an intentional attempt to erase memories of the war; the process of forgetting conveniently reinforced the nexus between neoliberalism and ethnicity to facilitate the elites' control of economic and political institutions. Makdisi (1997:692) identifies Solidere's reconstruction as "a concerted effort to wipe clean the surface of central Beirut; to purify it of all historical associations in the form of its buildings; to render it pure space, pure commodity, pure real estate" (Makdisi 1997:692). In discussions with Lebanese civil society activists I noted that they associated Lebanon's state imposed policy of forgetting with the act of rebuilding the city-centre. As one social movement activist noted: "the downtown is the core of the reconstruction ideology - that we don't need to look at the past. Yes, it is very simply part of the amnesia." Another activist explained to me:

The Solidere project came around and ... for me, it was just a catastrophe, it was part of a plan to erase memory and when you erase the memory of the downtown it is the most destructive thing that you can do to a city (interview, June 2015).

The regeneration of the city-centre not only abjured references to the civil war; the proliferation of upscale shopping malls, hotels and gated communities are deeply exclusivist. The gentrification and privatization of the downtown contradicts the historical role of Beirut 
city-centre for some Lebanese. Before the war the city-centre "served as a vibrant and cosmopolitan melting pot of diverse groups and socio-cultural transformations" (Khalaf (2012:90). Since the city-centre "was the place where different classes, religious sects, and ideologies interacted," its revitalization needed "to heal the wounds of the war" (Sawalha 2010:26).

In a society riven by sectarian segregation, Beirut city-centre prior to the war functioned as an important site of social centrality. The city-centre presented some degree of protection against the prevalent forces of ethnic separation and intolerance. A civil society activist reminisced:

Downtown Beirut was a place where you could not go to and stay entrenched in your confessional identity. It was a place where people needed to adjust to the fact that they are there with others who don't have the same colloquial perspective, who don't have the same beliefs, don't have the same origin but they needed to interact with (interview, June 2015).

The rebuilding of Beirut city-centre was vital to peacebuilding as it had the potential to create a rare shared public sphere in a society in which urban space is increasingly sectarianized or rendered exclusive to rich elites. Yet, the postwar reconstruction of the citycentre had a reverse consequence: it emptied the area of any spontaneous civic life, a "ghost town" as an activist described it. Rather than construct an ethnically segregated centre, the regeneration excluded most of the citizenry, a point noted by a civil society activist: "who can go to the downtown? You cannot go there unless either you are doing fancy shopping or if you have 10 dollars to pay for coffee" (interview, June 2015).

A simpatico relationship exists between the amnesic and exclusivist city-centre and the exacerbation of ethnic cleavages in the postwar era. A movement leader illuminated this point well: 
The urban idea of Soldiere - turning the downtown of Beirut into a kind of exclusive touristic resort has contributed to keeping the confessional system. The Lebanese need meeting points. What did we do in order to create physical and social meeting points since 1990 ? Nothing. This kind of savage privatization of the public space is just contributing to keeping the entrenchment and engulfment of each community (interview, June 2015).

A leader of another organization related to victims noted that:

\footnotetext{
When you know very well that all of the big projects undertaken in this country were just strengthening the rule of those former warlords who whitewashed their records thanks to Taef. You cannot tell me that with these people who promoted the religion of amnesia you can really build peace (interview, June 2015).
}

Lefebvre (1991) argued that urban space is not merely a "theatre" for sociopolitical conflicts but a constitutive dimension. The struggle by competing social and economic actors to control the meaning of space is a central part of how space is reproduced and utilized. As Khalaf (2012:109) argues, "the effacement of dilapidated vestiges of the past" as part of "clean state" ideologies is Lebanon has paradoxically resulted in a "public sphere pregnant with divergent versions and visions for past and future of city and country." Such movements, "if judiciously mobilized, become routes for forging new cosmopolitan identities and transcending loyalties and commitments" (Khalaf 2012:79). The struggle of Beirut's social movements to force the political elites and the wider society to deal with the legacy of the past, as a necessary part of peacebuilding, means that the city-centre represents a "battlefield in the long-running struggle over national identity and sectarian inequality in Lebanon" (Nagel 2002:719). It is to these movements that the paper now turns to.

\section{Victims' Groups}

The mobilization of victims' groups to access the truth about the disappeared and to demand that the perpetrators are held accountable represents the most visible consequence of what 
one activist called the "state religion of amnesia" in postwar Lebanon. Victims and the disappeared are, another activist noted, "the dirt swept under the carpet" in Lebanon's power-sharing structure. In response, victims' movements purposely protest in the citycentre to remind the state and wider society of the injustice of the disappeared and the dangers of a postwar order built on impunity and political sectarianism.

Towards these aims, SOLIDE, one of the victims' movements, began its protest campaign in December 1989 when activists formed a 24-kilometer human chain in the city-centre. In April 2004, the security forces attacked 500 SOLIDE protestors with water cannon after they gathered in the city-centre to submit a petition to the UN. In 2005, activists constructed a permanent tent in the city-centre directly in front of the UN building and within clear sight of the presidential place and parliament. Sitting outside the tent with some of the families of the disappeared, Ghazi Aaad, SOLIDE's spokesperson told me: "The tent is a reminder that there was a war and one of the things that remains after the war is the issue of the victims. It's a reminder in front of the parliament here, the government behind us." Adorned with pictures of the disappeared, the tent provides a focal point for the families and activists to gather and as a starting point for protests against the parliament and other government buildings.

Writing about the Mothers of the Plazo de Mayo in Argentinia, Gordon (1997) notes that the victims" movement deployed the power of "ghosts" to "haunt" the state authorities responsible for the disappearances. The act of disappearance is a primary tactic of terroristic groups and states that seek to maximize fear among the population. Illegal abductions generate what Taussig (1999) has called a "public secret," something widely known across the society but fear forbids people to speak openly on it. The objective of disappearances has two purposes. Firstly, it divests the individual from all forms of social identity. Secondly, it is a "procedure for producing ghosts to harrowingly haunt a population into submission" 
(Gordon 1997:115). Such organized terror is designed not only to destroy the opposition, but even the propensity for individuals to speak out. For Gordon (1997:112), the "truly unique contribution of the Mothers was their extraordinary understanding of haunting and its crucial place in a society fraught with state sponsored disappearance." In particular, the Mothers rejected the idea that their loved ones should be categorized as "dead" as this left them bereft of justice; instead the label of "the disappeared" signified that they wanted to call to account those responsible and ensure the return of the disappeared.

Similarly, in Lebanon, many of the leading activists for the disappeared refuse to accept the idea that their relatives are dead. On May 25, 1995, Law 434 was introduced by the Lebanese state, which provided "principles for declaring the missing dead" (Maalouf 2009; ICTJ 2014:15). Under the auspices of Law 434, any person missing for at least four years is legally classified as deceased, and the families are permitted to undertake legal procedures to record their deaths and even claim limited financial compensation. By categorizing "the disappeared" as legally dead, the political elites closed down any form of state-led investigation into finding the truth about those responsible for the crimes let alone attempting to retrieve the bodies (ICTJ 2014:16). The victims largely refused to acquiesce with Law 434. Through retaining the status of "disappeared" rather than "dead" for the missing, they maintain that the Lebanese political class and indeed wider society urgently needs to confront the legacy of the civil war since social silence keeps the wounds of history open. The amnesiac space of the city-centre is therefore challenged by the protest activities of the victims' groups.

\section{Ghostly Ruins}

Solidere's hegemonic control of the city-centre space is incomplete. As mentioned earlier, there are some buildings from the civil war period that Solidere are unable to expropriate. 
These ghostly ruins were major sites of violence during the war and bear the visible signs of destruction. These buildings, some of which are highly securitized, stand as rather anomalous presences in an environment dominated by the cult of the modern. Their real power, however, is that they disavow the wish of elites to enforce forgetting. Because of the deep symbolic meaning of these buildings, they are seen as important spaces for nonsectarian social movement actors demanding that the state opens up a systematic process of dealing with the past.

Designed in the 1920s by a renowned architect, the Barakat building in Beirut city-centre is known to locals as the Yellow House. A cosmopolitan melding of the various cultural influences that reflect Lebanon's multi-layered history, the building's location at the interface of west and east Beirut made it focal point for the militias during the civil war. After the war the building stood as a silent memory of the green line. Riddled by bullet holes, in the 1990s property developers planned to demolish the building to make way for new real estate. After a long campaign, in 2003 activists successfully forced the municipal authorities to seize the Yellow House. From then on, the owners have planned to use the building as a "Museum of Memory for the City."

In one sense, the building evokes an avant-garde fusion of architectural styles reflecting the city's rich multicultural composition. In a broader sense, the innovative design of the building allowed for various meanings and uses. In its original design, the building was constructed to curve around a corner of a city-centre junction. All of the building's rooms look out across the city, thus providing the residents with a unique vantage point. At the same time, the building has a main cleavage separating it into two wings, one looking at the Christian east of the city and the other peering at the Muslim west. The building's panoramic city views, however, made it ideal for snipers during the civil war. A campaigner explained her first thoughts after entering the building in 1992: 
The building was a killing machine. The snipers made their own construction and what was amazing is that they used the transparency of the place, you could see into the street without drilling a hole in the wall. I was thinking about how brilliant that sniper was and how brilliant that architect was and what this overlap meant in a city that seemed so contradictory. A building that was originally designed to interact with the city - to open up the city - and then the ingenuity of a sniper who used exactly that visual access to kill people in the city, to cut the city in two, and instead of making people interact with the city, it was used for killing. It was the same building but used for two different things (interview, June 2015).

The building's architectural cleavage - while connected by a unifying curved balcony symbolized an even deeper level of meaning for the city's contemporary history: the reproduction of generational conflictual divisions and the citizenry's rather hypocritical desire for unity.

\begin{abstract}
When you see the building from the outside, you see one building very well connected, but once you look at it from the inside you see that it has a very sharp cut, but at the same time, it's so flimsy. So for me it's like the city that was always cut in two - be it the Christian East and Muslim West during the civil war, be it the sectarian divisions now, be it the people who are for or against reconstruction - it reflects these continuous divisions. But when you hear these factions, they always say they love each other, they want Lebanon to be one (interview, June 2015).
\end{abstract}

"The building," the activist explained, "has all these layers of connotations that directly connect to the city. It is just like a mini Beirut." In sum, the architecture of building, its polysemic meanings and varied usages offered a dramatic setting for a museum of Beirut's history. The museum's potential to support a broader project of peacebuilding is outlined in a pamphlet created by activists:

The acknowledgement of the whole past needs to be a principle entrenched within the collective consciousness of all communities. Making this reconciliation of the past visible, accessible and shared contributes to the process of social reconciliation (Beit Beirut n.d.). 
For one activist, the museum's proposed role in reconciliation is thus:

I feel that this place has a healing property because it is a beautiful building that has been destroyed. It is an ingenious building that has been abused and you can see how something really important becomes used or abused for no reason. When you are there you are just forced to question the fact of why you go through a war; just starting the debate is enough ... I think that this is the only place that can do it but I also believe that the municipality doesn't understand this. We have fought to preserve the memory of the war (interview, June 2015).

The very campaign to remember the war is also a fight against the expropriation of the city by private interests and sectarian elites:

I was fighting against the people who thought that it's not worth preserving. The struggle to try and get the museum built symbolizes postwar Beirut, the fight against amnesia, the fight to preserve memory against money, the fight for history and identity that we are still facing every single day because we have no government and no hope (interview, June 2015).

\section{The Civil Campaign to Protect the Dalieh of Raouche}

The postwar privatization of Beirut quickly rolled outwards from the city-centre to embrace adjacent districts. A specific focus for this is the ongoing privatization of Beirut's natural shoreline. A law in 1995 allowed Solidere to reclaim nearly 800,000 square metres of Beirut's shoreline. Roughly 100,000 square metres of this land encompasses the Dalieh of Raouche, a natural heritage site that constitutes part of Beirut's shoreline along the citycentre.

Dalieh comprises varied meanings, memories and uses for Beirutis. The rich diversity of features - coastal cliffs on the landside and rock islands, protruding stone terraces and natural pool enclaves - provide natural habitats for native plants, insects, birds and marine fauna. Dalieh also derives socio-cultural significance for a number of groups. Dalieh is used by fishermen and 10 families live on the shore; elderly swimmers swim every day in the 
natural shallow pools; it is a place for gay men to surreptitiously meet; for families to picnic in the grassy hills; and a symbolic site for ethnoreligious groups commemorating religious events. A brochure published by campaigners to protect the site explains: Dalieh is "an 'open access shared space' for a wide variety of city dwellers" (Civil Campaign to Protect the Dalieh of Rouche 2015:1). Importantly, an activist pointed out to me, Dalieh "is the last part of Beirut where you can touch the sea without paying."

In early 2013 security men representing real estate companies moved into the site to evict the community of fishermen and a few weeks later work began work on a 377-metre barbed wire fence to block the entrance. Local activists immediately identified these steps as an attempt to enclose and privatize one of the last public spaces in the city. In March 2013, 40 activists working on environmental and public space issues, maritime protection and civic engagement met to discuss stopping the privatization of Dalieh. One of the campaign organizers explained to me that:

We were all aware of the issues and the controversies that took place after the civil war with the loss of centrality and the loss of gathering places and the increasing of private spaces and the encroachment on the whole maritime domain (interview, June 2015).

In November 2013 activists launched the "Civil Campaign to Protect the Dalieh of Raouche." A campaign booklet describes the movement as a collection of "individuals, environmental, cultural and civil groups who share a strong commitment to the preservation of Beirut's shared spaces, ecological and cultural diversity as the pillars of the city's livability" (Civil Campaign to Protect the Dalieh of Raouche 2015:2).

The power of ghosts and haunting informs the campaign of Dalieh. An activist explained that a fundamental part of the campaign is on detailing Dalieh's "sociocultural significance for the memory of the city and as one of the last natural open spaces that is not restricted." The 
movement has largely focussed on organizing on-site demonstrations and direct action against restricting access to Dalieh. The families of the fishermen protested against the evictions by holding a banner stating: "We don’t want speculators negotiating over our children's wellbeing." An activist recounted the campaign:

We placed a banner on the rock towards the water asking them to remove their construction from Rouche. A group of people came to a public demonstration where the mayor of Beirut was present and in the presence of a lot of media. We hung banners; there was an intervention on the fence, which is still there today, where kids knitted some figurines (interview, June 2015).

A banner unveiled by the activists at the site read:

The dream of our city does not lie in real estate development, but rather in public spaces and open access to the sea. The dream of the $3 \%$ is producing nightmares for $90 \%$ of the people.

As the movement developed, activists created a broad based campaign that embraced a mixture of platforms. A leading activist explained that the campaign evolved as a form of "research expert led activism." Part of this research is to determine whether the privatization of Dalieh constitutes illegal expropriation.

At its heart, the Civil Campaign to Protect the Dalieh of Raouche positions itself as a "rightto-the-city" movement. The campaign's brochure announces:

we are propelled by ... an uncontrollable urge to enshrine democratic and inclusive processes of decision-making in the production and organization of the everyday spaces of Beirut ... we perceive current disfigurations as momentary embodiments of the greed that has motivated building processes in the city. Our message is directed to all city dwellers; we invite everyone to join us in struggling for her/his right-to-the-city, a city where private capital cannot trump the desires of the urban majorities in enlarging and improving the city's shared commons (Civil Campaign to Protect the Dalieh of Raouche 2015:1). 
As a right-to-the-city movement, the campaign has direct consequences for peacebuilding. The movement's resistance against the ever-expanding project of privatization illuminates the impoverishment of public institutions and civic life in postwar Beirut. "How can you move forward in a country where nothing in the public interest comes first?" an activist asked me. This situation is emphasized by the fact that it is the sectarian elites who use their clientelistic networks to enrich themselves by the privatization of urban space. Yet, the expropriation of urban space does not only serve the economic interests of the sectarian leaders, it cements even further their position as leaders of ethnic communities. The shrinking circle of accessible public spaces in the city and across the state has the correlative outcome of narrowing opportunities for different social and ethnic groups to mix and engage in social relationships that transcend divisive cleavages. More acutely, the encroachment of privatized and exclusive spaces militates against the development of a shared public, civic identity necessary for democratic stability. An activist explained:

People don't belong, because we don't belong. We belong to our little circles, to circles of religion, because we don't have civic education ... Lebanon is not a country but a country club. You do not respect the country as a place where you owe and do things in return ... We had little uniting us before but the idea of having a downtown that was the melting pot of all the Lebanese, even that failed miserably (interview, June 2015).

\section{Conclusion: Return to Abu Rakhussa}

In the summer of 2015 more than 20,000 tonnes of rubbish amassed uncollected in Beirut's streets as Lebanon's power-sharing government, stuck in a fierce political deadlock, was unable to deal with the most routine features of governance. Thousands of protestors assembled in the city-centre to demand the government's resignation for allowing sectarian differences to supersede environmental and health concerns. Many protestors - reported as including "people from across the sectarian and political spectrum" (Aljazeera 2015) - wore 
symbolic refuse bags and paper masks to cover both the stench of the trash and the rotting political class (Nagle 2016:1).

After one protest, Solidere's chairman accused the protestors of "impeding the business of the commercial district in Downtown" and demanded the protestors leave the city-centre as they were "cheapening" it by transforming it into a new "Abu Rakhussa” (Daily Star 2015). The label "Abu Rakhussa" was telling; it translates as "father of the cheap," used to describe the working-class markets that characterized the city-centre before the civil war. A social movement activist responded: "We want to hold accountable everyone who robbed this country ... and we want to reclaim Downtown Beirut for the people ... the markets are coming back" (Daily Star 2015). In an attempt to retake the city-centre, thousands of activists recreated Abu Rakhussa for one night. They set up stalls in the city-centre to sell homemade good to highlight the exclusivity of upscale stores in the downtown district. One participant was recorded saying that "it brought us back 40 years to when we used to come down here and buy things. It's not like this anymore" (Daily Star 2015).

For Lefebvre, the city-centre can be a liminal social space in which concrete political alternatives are summoned. In this moment, “disparate heterotopic groups suddenly see, if only for a fleeting moment, the possibilities of collective action to create something radically different" (Harvey 2012:xvii). In divided cities, a radical difference is to remake the city a place of access, participatory democracy and inclusivity. Such a project is stimulated in the context of a postwar city in which neoliberal regeneration takes centre stage to supposedly foster peace and reconciliation. These districts are not only reconstructed, but space is programmed, rendered free of any memory of the city's violent recent history. In Beirut, this amnesia is not only about the role of ethnic leaders in the history of the war, but of the citycentre as a place of mixing, hybridity and encounter. The struggle of non-sectarian social movements to reinsert memory and livability into the city is a radical and pluralistic vision of 
the city. It challenges the divided city's status as a site of social segregation, in which ethnonational groups assert control over geographic areas and support ideas of enclosed and separate places. Considering the thoughts of Lefebvre (1996) on urban, participatory democracy, the ethnonational city can be reimagined as a site of renewed centrality, a place of encounter, an assemblage of difference which permits the full usage of moments and places.

\section{Endtnotes}

${ }^{1}$ Former warlords and military figures that are now political leaders include Suleiman Frangieh Jr (Mareda Movement), Walid Jumblatt (Progressive Socialist Party), Samir Geagea (Lebanese Forces), Nabih Beri (Amal) and Michel Aoun (Free Patriotic Movement) (see Nagle, 2016:79-80).

${ }^{2}$ These militias range across all of the ethnoreligious groups and include those associated with Hezbollah, Progressive Socialist Party, Amal and the Lebanese Forces. 


\section{Bibliography}

Aljazeera (2015) Lebanese protest against waste-disposal crisis, Aljazeera 26 July. http://www.aljazeera.com/news/2015/07/lebanon-beirut-trash-rubbish-crisis150725060723178.html (last accessed 27 August 2015)

Arendt H (1958) The Human Condition. Chicago, IL: University of Chicago Press.

Beit Beirut (n.d) Beit Beirut. No publication information

Cammett M (2014) Compassionate Communalism: Welfare and Sectarianism in Lebanon. Ithaca, NY: Cornell University Press

Civil Campaign to Protect the Dalieh of Rouche (2015) The Civil Campaign to Protect the Dalieh of Rouche. Beirut: The Civil Campaign to Protect the Dalieh of Rouche

Daily Star (2015) “Abu Rakhussa” brings pre-war nostalgia to downtown Beirut, Daily Star September 19. https://www.dailystar.com.lb/News/Lebanon-News/2015/Sep19/315892-you-stink-calls-on-supporters-to-join-abu-rakhussa-rally-in-downtownbeirut.ashx (last accessed 21 September 2015)

Edensor T (2005) The ghosts of industrial ruins: ordering and disordering memory in excessive space. Environment and Planning D: Society and Space 23(6):829-849.

Foucault M (1999) Religion and Culture. London: Routledge.

Gordon A (1997) Ghostly Matters: Haunting and the Sociological Imagination. Minneapolis, MN: University of Minnesota Press

Harris W (2012) Lebanon: A History, 600-2011. New York: Oxford 
Harvey D (2012) Rebel Cities: From the Right-to-the-city to the Urban Revolution. London: Verso

Hughes C (2015) Poor people's politics in East Timor. Third World Quarterly 36(5): $908-928$

International Center for Transitional Justice (ICTJ) (2014) Failing to deal with the past: What cost to Lebanon?, https://www.ictj.org/sites/default/files/ICTJ-Lebanon-ImpunityReport-2014.pdf (last accessed 27 August 2015)

Kassir S (2011) Beirut. Berkeley, CA: University of California Press

Keen D (2005) Conflict and Collusion in Sierra Leone. Oxford: James Currey.

Khalaf S (2012) Lebanon Adrift: From Battleground to Playground. London: Saqi

Leenders R (2004) Nobody having too much to answer for: Laissez-faire, networks, and postwar reconstruction in Lebanon. In S Heydemann (ed.) Networks of Privilege in the Middle East (pp. 169-200). Basingstoke: Palgrave

Lefebvre H (1991) The Production of Space. Oxford: Blackwell

— (1996) The right-to-the-city. In E Kofman and E Lebas (eds) Writing on Cities (pp 63-181). Oxford: Blackwell

Maalouf L (2009) Enforced Disappearances in Lebanon: A Nation's Unyielding Legacy. Beirut: Act for the Disappeared

Makdisi S (1997) Laying claim to Beirut: urban narrative and spatial identity in the age of Solidere. Critical Inquiry 23(3):660-705 
Marot B and Rigizi S (2012) The reconstruction of Beirut: sowing the seeds for future conflicts? Metropolitcs.eu, https://www.metropolitiques.eu/The-reconstruction-ofBeirut.html (last accessed 27 August 2015)

Millar G (2015) Investing in peace: foreign direct investment as economic restoration in Sierra Leone? Third World Quarterly 36(9):1700-1716

Mitchell D (2003) The Right-to-the-city: Social Justice and the Fight for Public Space. London: The Guildford Press

Nagel C (2002) Reconstructing space, re-creating memory: sectarian politics and urban development in postwar Beirut. Political Geography 21(5):717-725

Nagle J and Clancy M-A (2010) Shared Society or Benign Apartheid? Peacebuilding in Divided Societies. Basingstoke: Palgrave Macmillan

Nagle J (2009) Sites of social centrality and segregation: Lefebvre in Belfast, a “divided city." Antipode 41(2):326-347

— (2016) Social Movements in Violently Divided Societies: Constructing Conflict and Peacebuilding. Abingdon: Routledge

Picard E (2002) Lebanon: A Shattered Country. New York: Holmes and Meir

Richmond O.P (2011) Critical agency, resistance and a post-colonial civil society. Cooperation and Conflict. 46(4): 419-440

Roy, A. (2009). Civic governmentality: the politics of inclusion in Beirut and Mumbai. Antipode, 41(1):159-179

Salloukh B.F, Barakat R, Al-Habbal, J.S, Khattab L.W and Mikaelian S (2015) The Politics of Sectarianism in Postwar Lebanon. London: Pluto 
Smith N (2002) New globalism, new urbanism: Gentrification as global urban strategy. Antipode 34(3):427-450

Sawalha A. (2010) Reconstructing Beirut: Memory and Space in a Postwar Arab City. Austin, TX: University of Texas Press

Solidere (2009) Annual Report. Beirut: Solidere

- (2011) Momentum of Place, People in Motion: City in Scenes. Beirut: Solidere

— (2015) Beirut and its city-centre. January 22. http://www.solidere.com/citycenter/beirut-and-its-city-center (last accessed 1 February 2016)

Stoughton I (2014) The architectural legacies of war in art. The Daily Star April 28. https://www.dailystar.com.lb/ArticlePrint.aspx?id=254586\&mode=print (last accessed 27 August 2015)

Tagg J (1996) The city which is not one, in A King (ed.) Re-Presenting the City: Ethnicity, Capital and Culture in the 21st Century Metropolis (pp 179-182). Basingstoke: Macmillan

Taussig M (1999) Defacement: Public Secrecy and the Labor of the Negative. Stanford, CA: Stanford University Press

Till K (2012) Wounded cities: memory-work and a place-based ethics of care. Political Geography 31(1):3-14

Uitermark J (2004) Looking forward by looking back: May Day protests in London and the strategic significance of the urban. Antipode 36(4):706-727 
Wainwright O (2015) Is Beirut's Glitzy Downtown Redevelopment All That It Seems? The Guardian, http://www.theguardian.com/cities/2015/jan/22/beirut-lebanon-glitzydowntown-redevelopment-gucci-prada (last accessed 27 August 2015)

Zahar M-J (2005) Power-sharing in Lebanon: Foreign protectors, domestic peace, and democratic failure, in D. Rothchild and P. Roeder (eds.). Sustainable Peace: Power and Democracy after Civil Wars (pp 219-240). Ithaca, NY: Cornell University Press 